\title{
MEASURING PERFORMANCE OF ENGINEERING DEPARTMENT BY USING BALANCE SCORECARD (CASE STUDY IN PT. XYZ)
}

\author{
Fety Ilma Rahmillah
}

\author{
Department of Industrial Engineering, Faculty of Industrial Technology, Universitas Islam Indonesia \\ Jl. Kaliurang km. 14 Sleman Yogyakarta \\ E-mail:fety_rahmillah@yahoo.com
}

\begin{abstract}
ABSTRAK
Departemen Engineering adalah departemen yang sangat penting dalam PT. XYZ, karena departemen ini merupakan blue print facility yang mengemudikan operasional perusahaan. Namun, kinerja departemen ini belum pernah diukur dengan metode apapun. Penelitian ini menggunakan Balance Scorecard yang terdiri dari 4 aspek, yaitu aspek keuangan, pelanggan, pembelajaran dan pertumbuhan, dan proses bisnis internal untuk mengukur kinerja departemen engineering. Hasilnya: 1) Aspek keuangan memiliki sistem yang baik; 2) Perspektif pelanggan dianalisis menggunakan tingkat kepuasan pelanggan di mana 53,85\% tidak puas; 3) Pembelajaran dan pertumbuhan dianalisis menggunakan survei kepuasan karyawan dan menunjukkan bahwa 50\% puas; dan 4) Proses bisnis internal menunjukkan bahwa 66,67\% dari total proyek selama tahun yang diamati telah tercapai.
\end{abstract}

Kata kunci : Balanced Scorecard, Perspektif Pelanggan, Pembelajaran dan Pertumbuhan, Proses Bisnis Internal.

\section{INTRODUCTION}

Engineering department is an important department in PT. XYZ since this department is the blue print facility or center which driving the operation. It aims to design and optimize the production facilities so that production could reach the target. The function is primarily to act as professional advisors on all aspects related to the oil fields and report directly to Field Operation Superintendent (FOS). In addition, Engineering department should responsible for field data analysis, prepare and present special reports related to all aspects of production techniques, support the production operations on maintenance performance and production rate, as well as prepare accurate information and recommendations regarding the conditions and characteristics based on engineering analysis.

The strategy of this department is "In time finish project". It is based on company's strategy which is "Maximize Oil Recovery, Miminize Operational Cost, and
Environmentally Friendly". While the vision of company is recognized as a leading energy company with high integrity and environmentally oriented social concerns. The mission is looking for and developing energy resources in an innovative increasing profit to all interested parties by reference to standards of ethics and rules on environmental awareness and by optimizing the resources available locally and then grow together through partnership processes.

The responsibilities of engineering department are starting from Basic Engineering Design (BED), Front End Engineering Design (FEED), Detail Engineering Design (DED), Material Take Off (MTO), Review, Approval, Progress Report, EPC Tender Evaluation, As Built, and Documentation. The job was divided appropriately among the team which consists of a) Production and Process engineer; b) Mechanical engineer; c) Electrical engineer; d) Instrumental engineer; e) Pipeline engineer; f) Civil engineer; and g) Piping engineer. 
The performance of this department has not been measured by any kind of methods since it is a new department. Currently, continuous quality improvement of organizational performance is required. The aim of the present study is to evaluate the performance of engineering department by using Balance Scorecard with four perspectives inside, which are financial aspects, customers, internal business processes, and learning and growth. It is used because it has been adopted in more than half of all major firms (Spender, 2014), including oil and gas sector (Nortjé, Middelberg, Oberholzer, \& Buys, 2014; Ngari, 2014).

\section{LITERATURE REVIEW}

The Balanced Scorecard (BSC) is a tool to translate organization vision and strategy into a comprehensive metrics to assess performance. Essentially, BSC is a set of financial and nonfinancial measures relating to company critical success factors (Kaplan, 2010).

Corporate strategy, which is the basis for the preparation of a scorecard, was developed from the company's vision. This vision of the future gives the company a clear direction of the organization and helps workers to understand about the company and how they contribute to the company. Vision is also the liaison between the mission and basic values (core values) to be stable over time with its dynamic strategy.

There is a kind of agreement that the framework of a Balanced Scorecard consists of at least four general perspectives, namely financial, customer, internal business processes, and learning and growth (Kaplan \& Norton, 1992). Scorecard should describe the company's strategy, starting with the long-term financial goals, and then associate with various sequence measures that should be taken regarding the financial, customer, internal processes and workers as well as systems to produce long-term economic performance of the company desired.

\section{Financial Perspective}

This element is used to track the financial requirement and completement in an organization.

2. Customer Perspective

Customer Satisfaction level is used to assess the satisfaction level of customers toward engineering department's performance. It is measured by nine (9) statements which are completeness of project, changing during the project, speed in doing the project until approved, the way to solve the problems occured during the project, easeness of contacting the engineering department, clearness of information needed, clearness of advice needed, knowledge relevancy of the engineer dealt directly with, and helpfulness of the engineering department. Customer should gives a mark with the range of 1 up to 7 which symbolyzed very dissatisfied up to very satisfied for each statement.

3. Internal Business Process Perspective

This aspect is used to measure the criticalto-customer process requirement and accomplishment in organization. In this study, it is indicated by the amount of time to complete the Management of Change (MOC) which is categorized as good (1 month), medium (1-3 months), and bad (>3 months).

4. Learning and Growth Perspective

This perspective will be concentrating on how the organizations train and educate their workers as well as how organization utilized it to main the company competitiveness. Employee satisfaction survey was used to measure the employee's level of satisfaction. It can be used to know learning and growth of the department. There are 30 statements in the questionnaire should be assessed by the employees with the range of 1 up to 7 which symbolyzed very disagree up to very agree for each statement. It describes loyality of employee, leadership, work group, training, etc. 


\section{RESEARCH METHOD}

\subsection{Research Object}

The object of this study is Engineering Department of PT. XYZ.

\subsection{Research Subject}

The subjects are customers of engineering department within PT. XYZ (Internal customers). There are 60 customers which are Field Manager, Production Superintendent, Field Operation Superintendent, Field Human, Safety, and Environmental Superintendent, General Admin Superintendent, Construction and Maintenance Superintendent, 20 people of Production's crew, 14 people of Human, Safety, and Environmental's crew, and 20 people of Construction and Maintenance's crew. Whereas the employees of engineering department are 7 people, which are Production and Process Engineer, Mechanical Engineer, Electrical Engineer, Instrumental Engineer, Pipeline Engineer, Civil Engineer, and Piping Engineer.

\subsection{Study Procedure}

The study was started by observing engineering department and interviewing some people inside of engineering department and outside within PT. XYZ. Based on the observation and interview, the existing condition of engineering department can be known. Literature study was used to know the gap between the existing condition and the expecting condition. Then, questionnaires were used to measure the performance of engineering department. Review for the statements of questionnaire was done so that misunderstanding can be minimized and the result can represent the real condition. After the distribution of the questionnaires, the next step is collecting and processing data. Reliability test is used to know whether the instrument is reliable or not. Then, data analysis is done to take conclusion and provide recommendation.
Half of questionnaire of customer satisfaction was returned and four of them were unused due to incomplete admission filling. Whereas for the employees, from seven questionnaires, six questionnaires were returned with complete admission filling.

Reliability test is used to know how reliable the instrument is, so that the result can be responsibled. The result of reliability test for customer satisfaction questionnaire shows that the data is reliable, since the value of Alpha is more than $0.8(0.905>0.8)$. Whereas for employee satisfaction survey, the value of Cronbach's Alpha is 0.933 which is also more than $0.8 \quad(0.933>0.8)$ means that it is reliable.

\section{RESULTS AND DISCUSSION}

\subsection{Financial Perspective}

Financial system includes accounting system, financial capability, budgetary controls, and internal controls. In term of accounting system, there is chart of accounts and project cost ledger which provides the recording of expenditures for each program by requiring budget cost categories. The employees report their time and effort by using working time sheet computation. In financial capability, the company prepares financial statements at least annually and establishes line of credit.

There is also budgetary controls in effect (e.g. comparison of budget with actual expenditures on a monthly basis) to preclude in excess of total funds available for training, buying software, any cost such as overtime, hire a temporary employee, and so on. A safeguard is also available to ensure adequate internal controls such as accounting level approval. Due to access restrictiveness to the financial data, the quantitative data is not analyzed. 


\subsection{Customers perspective}

The customer perspective is analyzed based on customer satisfaction survey. Here, descriptive analysis is used to analyze the result and to know the level or condition of variables owned by respondent.

Table 1. Data Description for Customer Satisfaction's Variable

\begin{tabular}{|c|c|c|c|c|c|c|c|c|}
\hline Variable & \multicolumn{4}{|c|}{ Actual Score (empiric) } & \multicolumn{3}{|c|}{ Probability Score (hipothetic) } \\
\hline Stat & Xmax & Xmin & Mean & SD & Xmax & Xmin & Mean & SD \\
\hline $\begin{array}{c}\text { Customer } \\
\text { Satisfaction }\end{array}$ & 50 & 17 & 32 & 9 & 63 & 9 & 36 & 9 \\
\hline
\end{tabular}

The formula for hipothetic score is calculated based on these formulas.

$X_{\max }=7 x$ amount of item

$\mathrm{X}_{\min }=1 \mathrm{x}$ amount of item

Mean $(M)=\left(X_{\max }+X_{\min }\right): 2 \ldots \ldots \ldots \ldots(1)$

Standard Deviation $(\mathrm{SD})=\left(\mathrm{X}_{\max }-\mathrm{X}_{\min }\right)$ : 6.

The hipothetic score is used to categorize respondents based on formulas from Azwar (2005) as follows :

Very Dissatisfied : $\mathrm{X}<\mathrm{M}-1,5 \mathrm{SD}$

Dissatisfied : $\mathrm{M}-1,5 \mathrm{SD}<\mathrm{X}<\mathrm{M}-$

0,5 SD.

Average : $M-0,5 \mathrm{SD}<\mathrm{X}<\mathrm{M}+0,5 \mathrm{SD} .$.

Satiesfied : M+0,5 SD $<X<M+1,5 S D$

Very Satisfied : $M+1,5 \mathrm{SD}<\mathrm{X}$.

By using those formulas, it yields categorization as follows:

Table 2. Categorization for Customer Satisfaction's Variable

\begin{tabular}{|c|c|c|c|c|c|}
\hline Variable & Range of Score & Category & Amount & Statement & Percentage (\%) \\
\hline \multirow{4}{*}{ Statements of of } & $\mathrm{X}<2,5$ & Very Dissatisfied & 0 & - & 0 \\
\cline { 2 - 6 } Customer & $2,5 \leq \mathrm{X}<3,5$ & Dissatisfied & 2 & 4 and 8 & 22 \\
\cline { 2 - 6 } Satisfaction & $3,5 \leq \mathrm{X}<4,5$ & Average & 7 & $1,2,3,5$, & 78 \\
& & & & $6,7,7$ and 9 & \\
\cline { 2 - 6 } & $4,5 \leq \mathrm{X}<5,5$ & Satiesfied & 0 & - & 0 \\
\cline { 2 - 6 } & $5,5 \leq \mathrm{X}$ & Very Satisfied & 0 & - & 0 \\
\hline
\end{tabular}

Based on results above, half of respondents feel dissatisfied, in which $53,85 \% \quad(\mathrm{~N}=14) ; 19,23 \% \quad(\mathrm{~N}=5)$ satisfied; and $11,54 \%$ in position of dissatisfied and netral (each of them $\mathrm{N}=3$ ). While the rest is in very satiesfied category, which is $3,85 \%$ as shown in figure 1 .

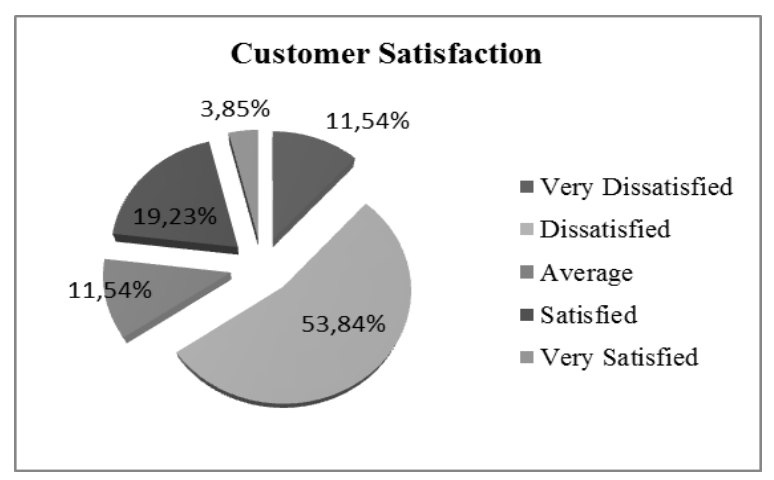

Figure 1. Percentage of Customer Satisfaction.

Table 3. Data Description for Statements of Customer Satisfaction's Variable

\begin{tabular}{|c|c|c|c|c|c|c|c|c|}
\hline Variable & \multicolumn{3}{|c|}{ Actual Score (empiric) } & \multicolumn{4}{|c|}{ Probability Score (hipothetic) } \\
\hline Stat & Xmax & Xmin & Mean & SD & Xmax & Xmin & Mean & SD \\
\hline Statements of & 3,77 & 3,35 & 4 & 0,12 & 7 & 1 & 4 & 1 \\
Customer \\
Satisfaction
\end{tabular}

Analysis for each statement is to know the position of each statement and it can be seen on Table 3. By using categorization formula from Azwar (2005), the results as shown in table.4.

Table 4. Categorization for Statements of Customer Satisfaction's Variable

\begin{tabular}{|c|c|c|c|}
\hline Variable & $\begin{array}{c}\text { Range } \\
\text { of } \\
\text { Score }\end{array}$ & Category & Amount \\
\hline & $\mathrm{X}<$ & Very & 3 \\
22,5 & Dissatisfied & \\
$22,5 \leq$ & & \\
& $\mathrm{X}<$ & Dissatisfied & 14 \\
31,5 & & \\
Customer & $31,5 \leq$ & & \\
Satisfacti- & $\mathrm{X}<$ & Average & 3 \\
on & 40,5 & & \\
& $40,5 \leq$ & & \\
& $\mathrm{X}<$ & Satisfied & 5 \\
& 49,5 & & \\
& $49,5 \leq$ & Very Satisfied & 1 \\
\hline
\end{tabular}


From nine statements, seven statements are categorized as average. They are completeness of project, changing during the project, speed in doing the project until approved, easeness of contacting the engineering needed, clearness of information needed, clearness of advice needed, and helpfulness of the engineering. For the completeness of the project whether it is already met the Management of Change (MOC) or Plan of Development (POD), it is rational if the category is netral since from 15 projects during year observed, there are 5 projects which are still in progress. However, it has to be remembered that engineering department still has time to finish their responsibility since there is three months left.

For the changing during the project, not all of the customers really know about this information because usually it is only related to the customer who ordered or sent WO (Work Order). The speed in doing the project are very relative due to the business of the department. For the others such as easeness of contacting the engineering needed, clearness of information needed, clearness of advice needed, and helpfulness of the engineers, the customer's assessment is very subjective so that average position is rational. Whereas two statements about the way to solve the problems during the project and relevancy of engineer knowledge deal with are categorized as dissatisfied. For the way to solve the problems during the project, it is subjective. Where as for the relevancy knowledge of the engineer, actually, it can be categorized as relevan or elligible for their position due to all of them have proper and good track record related to their job. However, it is possible that not all customers know about it and may be in their mind, the experience of the engineering is less since all of them are fresh graduate.

\subsection{Internal Process}

The internal perspective relates to MOC which is to ensure that the system can operate well. The task of this department is from issue for review until approval. Based on MOC data during year observed, the projects which are in complete or approved condition are 10 out of 15 projects or $66,67 \%$. There are 5 projects which are still in progress with variative rate of percentage and categorized as bad since the time to finish the project is more than 3 months. Whereas from 10 completed projects, 4 projects are categorized as bad and others 6 projects are categorized as good.

\subsection{Learning and Growth}

Learning and growth relates to employee satisfaction level. Therefore, it is analyzed by using employee satisfaction survey. Table 5 shows data description for employee satisfaction.

Table 5. Data Description for Employee Satisfaction's Variable

\begin{tabular}{|c|c|c|c|c|c|c|c|c|}
\hline Variable & \multicolumn{4}{|c|}{ Actual Score (Empiric) } & \multicolumn{4}{|c|}{ Probabilty Score (Prothetic) } \\
\hline Stat & Xmax & Xmin & Mean & SD & Xmax & Xmin & Mean & SD \\
\hline $\begin{array}{c}\text { Employee } \\
\text { Satisfaction }\end{array}$ & 170 & 99 & 143 & 25 & 210 & 30 & 120 & 30 \\
\hline
\end{tabular}

By using the same categorization formula from Azwar (2005), the results can be seen in Table 6 and Figure 2. Most of respondents having employee satisfaction variable in category of satisfied, which is $50 \%(\mathrm{~N}=3)$. Whereas others, which is having customer satisfaction in category of dissatisfied, netral, and very satisfied, each of them is $16,67 \%$ $(\mathrm{N}=1)$. 
Table 6. Categorization for Employee Satisfaction Variable

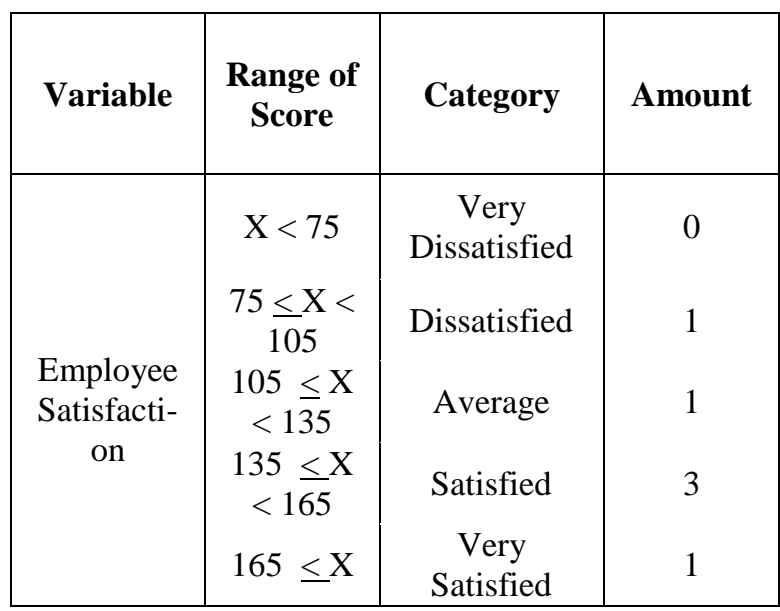

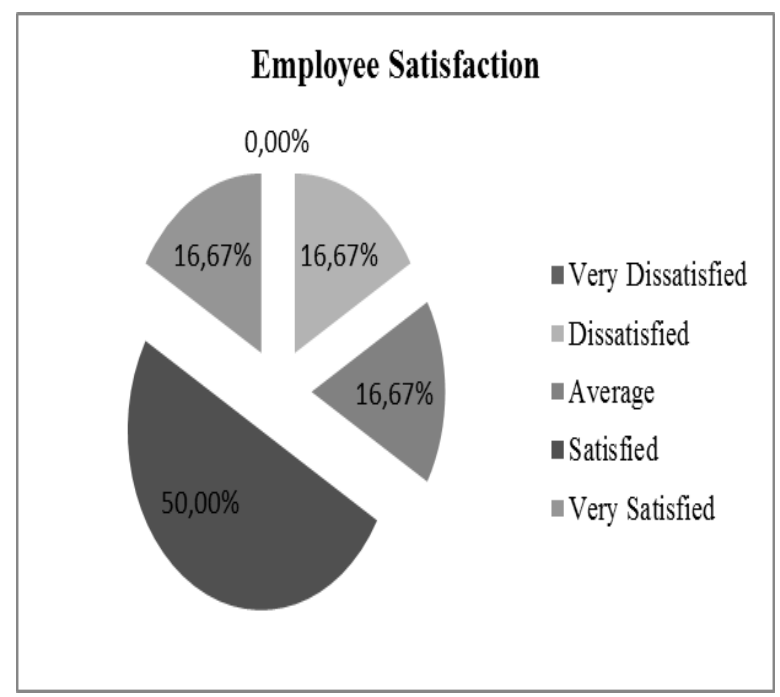

Figure 2. Percentage of Employee Satisfaction.

The two statements are number 18 and 27 which are "I feel not overload with my work" and "Promotions are handled fairly here". These two statements could be as a complaint from employees to the company, and the management system has to be improved in order this condition will not happen in a long time. While for the workload, trainings can improve skills and abilities of employees to maximize their performance in doing jobs.
Table 7. Categorization for Statements of Employee Satisfaction Variable

\begin{tabular}{|c|c|c|c|c|c|}
\hline Variable & Range of Score & Category & Amount & Statement & Percentage $(\%)$ \\
\hline \multirow{5}{*}{$\begin{array}{l}\text { Statements } \\
\text { of } \\
\text { Customer } \\
\text { Satisfaction }\end{array}$} & $X<2,5$ & $\begin{array}{c}\text { Very } \\
\text { Dissatisfied }\end{array}$ & 0 & - & 0 \\
\hline & $2,5<X<3,5$ & Dissatisfied & 2 & 18 and 27 & 6,67 \\
\hline & $3,5<X<4,5$ & Average & 8 & $\begin{array}{l}14,15,16, \\
17,19,21 \\
22, \text { and } 24\end{array}$ & 26,67 \\
\hline & $4,5 \leq X<5,5$ & Satisfied & 12 & $\begin{array}{c}2,3,5,7,8, \\
9,11,13, \\
23,25,26 \text {, } \\
\text { and } 30\end{array}$ & 40 \\
\hline & $5,5 \leq X$ & $\begin{array}{c}\text { Very } \\
\text { Satisfied }\end{array}$ & 8 & $\begin{array}{l}1,4,6,10 \text {, } \\
12,20,28 \text {, } \\
\text { and } 29\end{array}$ & 26,07 \\
\hline
\end{tabular}

Eight statements which are still in average position have to be increased to the next level. Those are statement number 14, 15, $16,17,19,21,22$, and 24 as shown in Table 8.

Table 8. Statements Which are In Middle Position

\begin{tabular}{|c|c|}
\hline No. & Statement \\
\hline 14 & $\begin{array}{l}\text { The goals and philosophies are clearly } \\
\text { communicated }\end{array}$ \\
\hline 15 & $\begin{array}{l}\text { The policies and procedures are } \\
\text { consistently implemented }\end{array}$ \\
\hline 16 & $\begin{array}{l}\text { The Head Start mission makes me feel } \\
\text { that my job is important }\end{array}$ \\
\hline 17 & This company is a \\
\hline 19 & There is no backlog everyday for my job \\
\hline 21 & $\begin{array}{l}\text { The wage is in line with the job } \\
\text { responsibility }\end{array}$ \\
\hline 22 & $\begin{array}{l}\text { The reward given is appropriate with the } \\
\text { performance achieved }\end{array}$ \\
\hline 24 & The work hours are comfortable \\
\hline
\end{tabular}

\subsection{Causal Relationship of Four Perspectives in BSC}

Papenhausen and Einstein (2006) underlined that successful BSC implementation requires active contributions from everyone in the organization. 
While to achieve sustainable business successes, an effective performance management system needs to be implemented and controlled (Babber, 2012/2013). Causal relationship of four perspectives of Balanced Scorecard for Engineering Department can be described as follows. If it is seen from learning and growth perspective where $50 \%$ of employees are satisfied, and only 2 statements $(6,67 \%)$ which grouped in dissatisfied so that the performance of engineering department should be good enough. It should give an efficient internal business process and it has been proven by $64,29 \%$ of time to finish the project (MOC). Then, the internal business process will influence the customer satisfaction. However, the result of customer satisfaction shows disstisfaction as much as 53,86\%. According to Kaplan and Norton (2001), customer should be put at the top of the strategic map. There is something missing here because if the input is good, it should yield the good output. It might be happened due to miscommunication or information doesn't transfered well. The various types of customers and the different necessity also influence the result. The financial should be proper allocated to the development of employees so that it will improve the performance and give influence to the internal process, learning and growth, and made customers pleased.

\section{CONCLUSION}

In the nutshells, Balanced Scorecard approach has become commonly used as one of the most sufficient business tools obtainable in the era of business firms. The result of performance measurement of Engineering Department by using Balanced Scorecard can be analyzed from four perspectives: 1) The financial aspect has a good system; 2) The customers perspective analyzed by using customers satisfaction level where $53,85 \%$ is dissatisfied 3 ) Learning and Growth is analyzed by using employee satisfaction survey and shows that $50 \%$ is satisfied; and 4) The internal business process shows that $66.67 \%$ of total project during year observed has been done.

\section{REFERENCES}

Babber. Integrated reporting and sustainability go hand in hand. Financial Management, 7, 2012 / 2013.

Kaplan, R. \&. The Balanced ScorecardMeasures that Drive Performance. Harvard Business Review, 70(1), 71-79, 1992.

Kaplan, R. S, Transforming the balanced scorecard from performance measurement to strategic management: part I. Accounting Horizons, 15(1), 87-104, 2001.

Kaplan, R. S. Conceptual Foundations of the Balanced Scorecard. Working Paper: Harvard Business School, 2010.

Ngari, M. M. Application of Balanced Score Card as a Strategy Management Process Tool by Kenya Petroleum Refineries Limited. School of Business, University of Nairobi, 2014.

Nortjé, C., Middelberg, S. L., Oberholzer, M., \& Buys, P. W. Developing a sustainable balanced scorecard for the oil and gas sector. Environmental Economics, 5(4), 5260, 2014.

Pietrzak, M., Paliszkiewicz, J., \& Klepacki, B. The application of the balanced scorecard (BSC) in the higher education setting of a Polish university. Online Journal of Applied Knowledge Management, 3(1), 151-164, 2015.

Spender, J. C. Business Strategy. Managing Uncertainty, Opportunity, \& Enterprise. Oxford: Oxford University Press, 2014. 